\title{
China's Rapid Economic Transformation and the Active Changes of its African Policy
}

\author{
Ehizuelen Michael Mitchell Omoruyi
}

Center for Nigerian Studies at the Institute of African Studies, Zhejiang Normal University, mmacroe@yahoo.com

\begin{abstract}
The pace and scale of China's economic transformation have no historical precedent. Since opening up to foreign trade and investment and implementing free market reforms in 1979, China has been among the world fastestgrowing economies. China is now the world largest economy (on a purchasing power parity basis). The paper examines China's rapid economic rise and the subtle changes that it has instituted in its foreign policy towards Africa. The author argues that since 1980s, China's foreign policy, more specifically, its African policy, has been decided by its strategy of development, and therefore undergone two strands of foreign policy changes in China Africa policy i.e. a shift from ideological considerations to economic diplomacy and a shift from a single form of aid to multiple channels of cooperation. In contrast to most analysts' claim that China's policy changed in recent years owing to its thirsty for oil and other natural resources in Africa. The change is closely linked with the transformation of Chinas' grand strategy. To analyze foreign policy change, the paper adopts Joakim Eidenfalk (2006) foreign policy change model which is one of the most relevant when applied to China's relations with Africa.
\end{abstract}

Keywords: Africa, China, Economic Reform, Eidenfalk Model, Policy Change

\footnotetext{
*Self-set Project of Zhejiang Provincial Key Research Base of Philosophy and Social Sciences -Center for African Studies at Zhejiang Normal University Project No. 16JDFZ03ZS
}

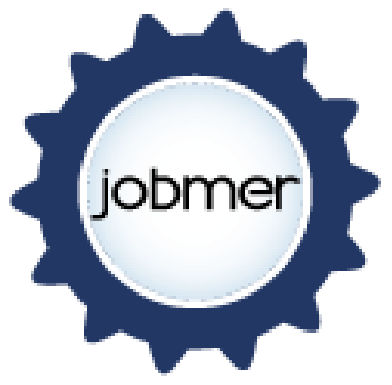

Journal of Business Management and Economic Research Vol.2, Issue.2, 2018 pp.7-34

Doi: 10.29226/TR1001.2018.18 


\section{Introduction}

China's rapid rise has puzzled several individuals, including economists. The meteoric rise over the past half century is one of the most striking instances of the influence of opening an economy up to the global market. Over that period China has undergone a shift from a largely agrarian society to an industrial powerhouse. In the process, it has seen sharp upsurges in productivity and wages that have permitted China to turn out to be the world's second-largest economy. How could China with over 1.3 billion people transform itself relatively suddenly from a vastly impoverished agricultural land into a formidable economic powerhouse when so many other small countries have been unable to do so in spite of their more favorable socialeconomic conditions? According to Yi Wen, among several conflicting opinions that have emerged to interpret China's rise, two stand out as the most popular and provocative. Firstly, the Chinese growth is viewed has hyper-growth as an enormous government-engineered bubble. Most analysts think it is not sustainable and will collapse because China has no democracy, no human rights, no freedom of speech, no rule of law, no Western-style system, no well-functioning markets, no private banking sector, no protection of intellectual properties, no capability to innovate (other than copying and stealing Western technologies and business secrets) nor a host of several other things that Western nations have possessed for centuries and have proved essential for Western prosperity and technology dominance (Wen, 2016). Based on this opinion, the bubble will burst at the expense of China's population and environment.

Secondly, other analysts view China's remarkable rise simply as destiny. They believe that China is returning to its historical position: the Chinese had been one of the wealthiest countries and greatest civilizations (alongside India) from at least 200 B.C to 1800, the dawn of the Industrial Revolution in England (See Figure 1) it was only a matter of time for China to reclaim its historical glory and dominate the world once again. "Let China Sleep, for when the Dragon awakes, she will shake the world." The saying is attributed to Napoleon ${ }^{1}$ and he seems to have been right because the dragon is awake. However, neither view is supported by concrete economic analysis, instead of being either on prejudice or naïve extrapolation of human history. The question now is how could a country with all those adverse elements for innovation and business be capable to grow at a double-digit annual rate for many decades and transform itself in such a short time from an impoverished agricultural economy into a formidable manufacturing powerhouse? If culture or ancient civilization is the clarification, then why is it that Greek, the Egyptian, and other great empires are not bursting onto the global arena? (Wen, 2016).

\footnotetext{
${ }^{1}$ Napoleon and his view on China August 18, 2008. Retrieved from http://wanderingchina.blogspot.com/2008/08/ napoleon-and-his-view-on-china.html.
} 
Ehizuelen Michael Mitchell Omoruyi, 2018, Vol.2, Issue.2, pp.7-34

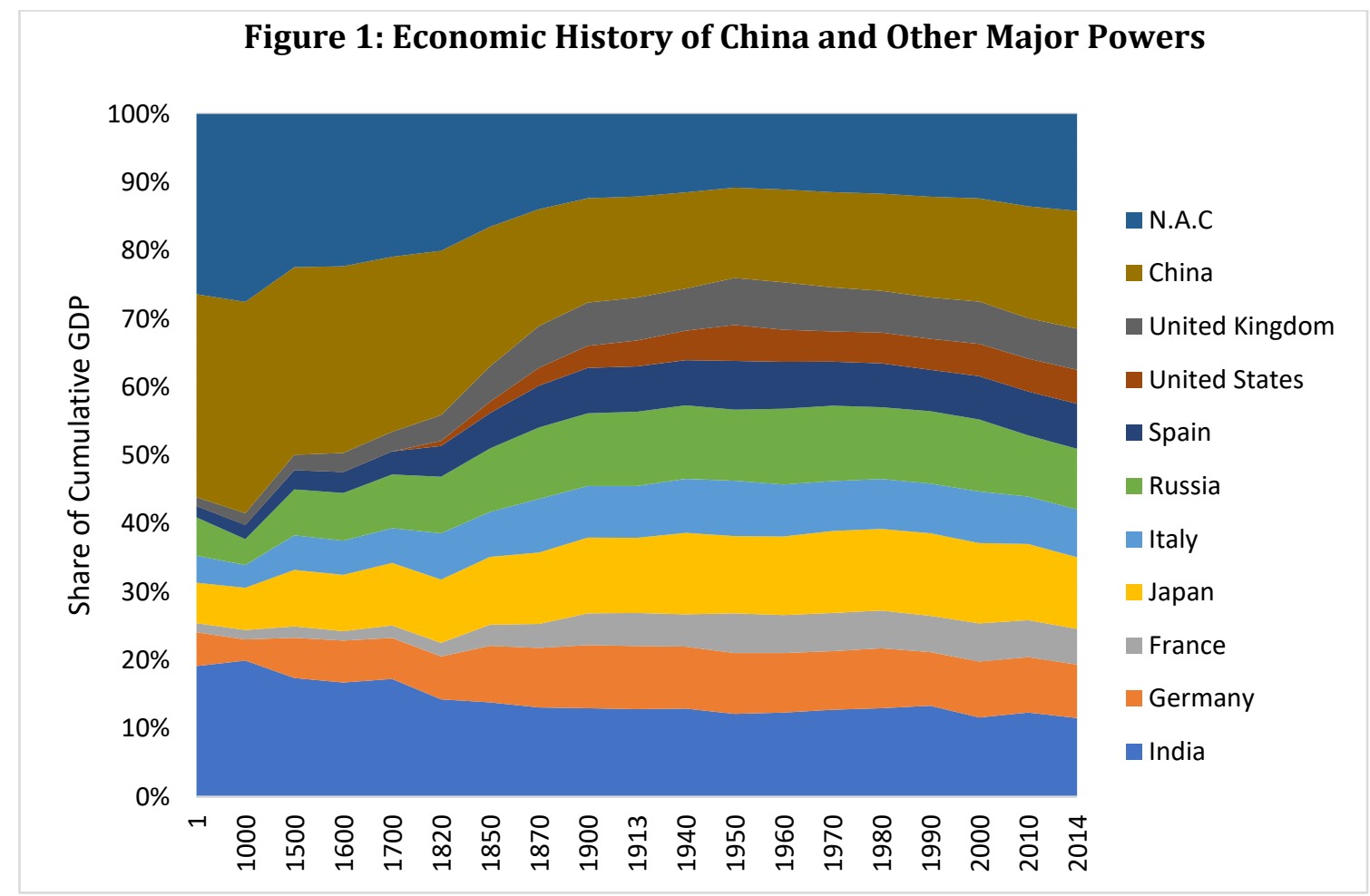

Source: Wen, 2016

Note: N.A.C represents Non-Asian Ancient Civilizations (Greece, Egypt, Turkey and Iran)

Note: The cumulative gross domestic product is that for all the nations listed and represents at least 70 percent of the total for the world at any given time, with the rest offered by smaller nations

The success of the Chinese economic reform that started in 1978 is frequently described by experts as one of the most remarkable success narratives in modern times. In 1978, China was one of the poorest nations in the world. The real per capita GDP in China was only one-fortieth of the United States level, and one-tenth the Brazilian level. China had a GDP per capita level similar to Zambia and lower than two-thirds of the African average. From 1979 (when economic reforms started) to 2016, China's real gross domestic product (GDP) grew at an average annual rate of approximately 10 percent $^{2}$, raising per capita GDP almost 49 -fold. China per capita GDP soared from over $\$ 200$ in 1978 to over $\$ 8000$ in 2015. China is one of the few nations in the developing world that has made progress in reducing its total number of poor people. Chinese official documents indicate that the number of poor people in China fell dramatically. Between 2011 to 2015, the total rural population lifted out of poverty was 109.92 million (Xinhua, 2016). In total, 800 million people are now living a poverty-free life in the past thirty-two years which amounts to over 70 percent of global poverty reduction over that period - an unparalleled accomplishment (World Bank, 2016). Following the process of China's phenomenal economic reforms and high rate of economic growth, the number of rural poor had fallen from 770.39 million in 1978 to 55.75 million by 2015, with the incidence of poverty dropping from 97.5 percent in 1978 to 5.7 percent in 2015 making China the first developing country to meet the Millennium Development Goals set by the United Nations. This spectacular achievement came as a result of China's poverty alleviation framework which consisted of three key components: pro-poor economic growth policies, a rural social safety net and developmentoriented poverty reduction strategies and programs (Liu Jian et al, 2009).

\footnotetext{
${ }^{2}$ China's economic reform process began in December 1978 when the Third Plenum of the Eleventh Central Committee of the Communist Party adopted Deng Xiaoping's economic proposals. Implementation of the reforms started in 1979
} 
China has emerged as a major global economic power. It is now the world's largest economy (on a purchasing power parity) manufacturer, merchandise exporter and importer, and holder of foreign exchange reserves. Figure 2 displays the manufacturing output of top five nations globally. In the early 1970s, China produced very few manufactured products - a tiny fraction of the United States level. Around 1980, China's manufacturing started to take off, surpassing the developed nations one by one, overtaking the United States in 2010 to turn out to be the number one manufacturing powerhouse globally. China's growing economic power has led it to become increasingly involved in international economic policies and projects, particularly in regards to infrastructure development. Such policies include the One-Belt, One Road initiative and the creation of two investment banks: the Asian Infrastructure Investment Bank (AIIB) and the New Development Bank (NDB). China is projected to spend over $\$ 1$ trillion on these initiatives. If successful, China's economic initiatives could significantly expand export and investment markets for China and upsurge its "soft power." China's speedy economic growth has led to a substantial upsurge in bilateral commercial ties with African nations.

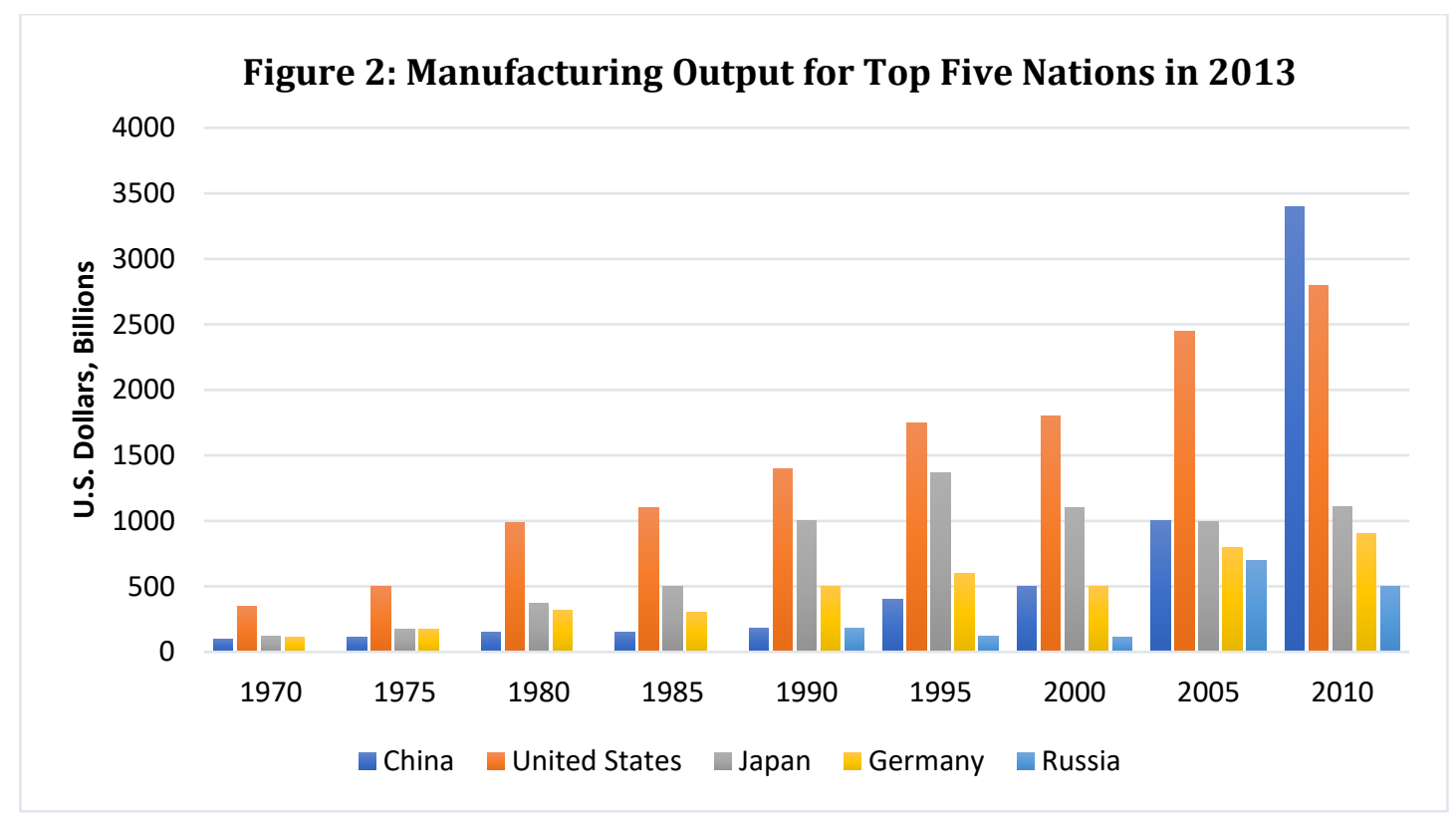

Sources: Wen, 2016

This research paper provides insights into the status of the Sino-Africa relationship by offering background on China's economic rise; describe its current economic structure as well as China's Africa policy change. The rest of the paper is structured as follows: Section 2 present an overview of the miraculous growth rate of China's economy, by interpreting China's development strategies. The section further discusses the four basic types of explanation that will help us understand China's remarkable economic success. Section three considers the policy level, investigating the previous relationship from 'Five Principles of Peaceful Coexistence in the Bandung Conference in 1955, to 'Four Principles of Chinese Cooperation with Africa' in 1982, to 'a Fresh Strategic Cooperation' in 2006. The section also looks at China's policy towards Africa; it concludes that China's policy towards African nations has shifted from unconditional aid; and that 'mutual-benefits' has turned out to be the 
priority. Section 4 looks at the three signs of changes in China's Africa Policy and what it means for Africa nations. Section 5 concludes the paper.

\section{The Interpretation and Understanding of China's Development Strategies}

The People's Republic of China (PRC) was founded in 1949 by Mao Zedong. Over the past sixty years, we can clearly distinguish two major phases in China's economic development: the Maoist phase (1949-1977) and the reform phase (1978-onwards). The Maoist period in China is, above all, marked by selfreliance and isolation from the world economy. The Deng Xiaoping period in China is, above all, marked by opening up to the rest of the world. China's understanding of the recent theme has changed from "war" and "revolution" to "peace" and "development". The communication between diplomacy and economy was overturned, for instance, the idea that economy should serve diplomacy was changed to that of diplomacy serving the economy (Anshan, 2007). The three decades of transformation has brought a speedy growth of Chinese economy. China opted for an indigenous solution to their economic backwardness, their economic transformation holds a special lesson for African nations. The three decades of economic transformation is nothing short of a miracle; this remarkable achievement indicates what a nation with determination, sacrifice, vision, and confidence can attain.

In the international stage, conflict or fighting is not the single means to attain success, the international relation is not a zero-sum game, the win-win strategy does work (Anshan, 2007). The miraculous growth rate of China's economy has prompted a great deal of study, particularly among economist. One of the economists is Jefferson (2008) who offers an excellent review of China's reform experience and on how the economics literature has tried to clarify that experience. One strand of other economic literature decomposes China's economic growth into labor, capital, technology, and institutional change components. Most of these quantitative studies (Lin, 1992; Fan, et al., 2004) find that institutional change accounts for a significant proportion of the observed economic growth since the reform. Additionally, the structural change from low-productivity agriculture to more productive industrial and service sectors also contributed to rapid economic growth. This part of the paper will discuss four basic types of explanation of China's remarkable economic success: (1) "comparative advantage" (and conditional convergence); (2) "incentive matter" (fiscal decentralization and realignment of incentives towards growthmaximizing activities); (3) experimentation (as an economic and political discovery mechanism); and (4) pressure and crisis as inducers of reform. 


\section{The Issue of Realigning the Economy in the Direction of Comparative Advantage Counts}

No credible perspective on the Chinese economy can ignore the amazing economic gains over the past 33 years during which growth of the economy augmented sharply creating hundreds of millions of employment and raising the incomes throughout China. Some experts argue that China's rapid rise since the reform is chiefly due to the rebalancing of China's development strategy away from a central focus on heavy-industry and in the direction of more laborintensive sectors (Lin, 2007). When the People's Republic of China (PRC) was founded in 1949, there was the dearth of capital in China and the Chinese were isolated from the international community. Influenced by the experience and ideology of the Soviet Union, in the 1950s, the central planning of industry (with an emphasis on the heavy industry) was introduced, modeled on the fiveyear plans of the Soviet Union. During this period, the Chinese placed the development of the heavy industry as their top priority if the country was to catch up with the developed countries as soon as possible. In order for the Chinese to attain this objective, the Chinese government suppressed the procurement price for grains, restricted rural migration, and set up some barriers between rural and urban residents. Due to the fact that this strategy was capital intensive, it violated China's comparative advantage, which was defined by limited capital and abundant labor, and led to almost thirty years of stagnation in per capita income.

Based on the famous Heckscher-Ohlin theory in international economics, adopting the law of comparative advantage on basis of factor endowments, a nation could export more products and gain more speedy accumulation of physical capital so that it may have a sustainable growth in the economic development. As far as a labor abundant underdeveloped nation is concerned, it has the potential competitive power in the global market for labor intensive products. Since 1978, the government of China has been pursuing the outwardlooking export-oriented strategies and with the advantage of vigorous FDI activities, it could convert its potential competitive power in labor intensive manufacturing into the actual one. Due to this advantage, the Chinese government has shifted its development strategies toward more labor-intensive sectors, to begin with, agriculture, and then progressively export-oriented rural industries. In the international context, the Chinese government possesses a clear comparative advantage in the labor-intensive manufacturing sector. There was an enormous inflow of foreign direct investment into China due to China's cheap labor after introducing the open-door policy.

As a result, both labor resources and capital were more efficiently distributed, which greatly bolstered economic efficiency. According to Krueger (1984), the 
author believes that the Chinese development path thus re-emphasizes the significance of adhering to comparative advantage in creating labor-intensive and export-oriented economic growth. Notably, a variation of this issue is that realignment in the direction of comparative advantage may be essential for augmented growth, but is not by itself adequate. According to Ravallion and Chen (2008), the authors debate that the Chinese post-1978 economy also profited from several social and infrastructural investments of the pre-1978 era, particularly pertaining to health, transport infrastructure, and education. Therefore, they raise a fairly standard idea of conditional convergence to clarify the Chinese post-1978 catch-up.

\section{The issue of incentives Counts During Economic Reforms}

Scholars have proposed a number of theories to explain the success of China's economic reforms in its move from a planned economy to a socialist market economy despite unfavorable factors such as the troublesome legacies of socialism, considerable erosion of the work ethic, decades of anti-market propaganda, and the "lost generation" whose education disintegrated amid the disruption of the Cultural Revolution ${ }^{3}$. Another theory focuses on internal incentives within the Chinese government, in which officials presiding over areas of high economic growth were more likely to be promoted. Scholars have noted that local and provincial governments in China were "hungry for investment" and competed to reduce regulations and barriers to investment to bolster economic growth and the officials' personal careers. According to Easterly (2002), the author argues that the most significant principle of economics is that the issue of incentives counts. Note that several of the reforms - dismantling of the communes and replacement by household farm plots liberalization of the Township and Village Enterprises (TVEs) and the opening of the coastal regions - were radical measures introduced quite rapid at the end of the 1970s and early 1980s. In these areas, there is little to distinguish the pace of the reform in China with that of Eastern Europe. The dismantling of the communes in 1979 covered approximately 790 million people, or 81 percent of the population, and was effectively attained in a brief period of 30 months. Irrespective of all these developments, Lin (1990) asserts that during the planning period China's rural communes were dogged by weak incentives because of free rider problems, particularly in agricultural production. During this period, the farmers did not want to work hard for the reason that the fruits of their toil were shared among others, rather than just themselves. In the same way, the state-owned enterprises (SOEs), shirking was also reported to be a widespread problem (Xu, 2003), and several SOEs made important losses. One

${ }^{3}$ Calhoun, Craig; Wasserstrom, Jeffrey N. (2003), "The Cultural Revolution and the Democracy Movement of 1989: Complexity in Historical Connections", in Law, Kam-yee, The Chinese cultural revolution reconsidered: beyond purge and holocaust, Palgrave Macmillan, p. 247, ISBN 978-0-333-73835-1, retrieved 2011-10-20 
of the key issues of the market-oriented reform surveys on China is that the post-1978 government offer strong incentives for the individual - including farmers, managers, and local officials - to upsurge investment and improve productivity.

The development of the incentive approach also had the effect of immediately resulting in a much fuller utilization of long-term investments made by the State in agricultural research and development, and other infrastructure. According to Fan, (1999) and Lin, (1992), they asserted that within the space of some years, agricultural productivity almost doubled. This development occurred as a result of the rural reform that triggered the economic growth and reduced the number of poor people in just a short period of time (Ravallion and Chen, 2008). Numerous literature has paid more attention to fiscal decentralization as the key motivating factor in China's economic growth (Cheung, 2008). During central planning, local governments had to turn in most of their local revenues to the central government, and there was no obvious rule as to how central finances were to be devolved to lower governments. China has adopted a series of fiscal reforms since the 1980s targeting at improving the fiscal contract arrangements between diverse levels of governments. After the fiscal reforms, local and upper-level governments shared fiscal revenues according to a predetermined formula. Since local governments can keep a significant portion of the augmented local revenues, they face stronger incentives to upsurge local revenue. Strong incentives for local governments to attain speedy economic growth helps to clarify the reason China has grown so fast in spite of the well-defined property rights protection in the de facto legal system (Zhang, 2007). Also, the competition serves as the disciplinary mechanism by which local governments offer de jure protection of investors' property rights. The existence of strong growth-oriented incentives also clarifies the reason the protection of the property rights of other groups, like farmers, has been weak (Zhang 2006a). Above all, China's central government has employed both personnel policies and fiscal incentives to make sure that local governments employ their financial empowerment to augmented economic growth. Therefore, although the principle of incentives is rather universal, the particular forms employed to improve incentives in China may not be easily transferable.

\section{The Issue of Experimentation Counts During Economic Reforms}

Policy experimentation points to political-administrative procedures and initiatives that allow to discover or test novel instruments of problem-solving and thereby propel broader-based policy innovation or institutional adaptation in a given polity, economy or society. The term has come to renewed prominence in the discussion about the political processes behind China's 
economic rise since the beginning of Chinese economic reform policies in 1978. ${ }^{4}$ In the economic stage, the Chinese reformers employed more explicit experimentation ${ }^{5}$ to promote economic learning and overcome political resistance to reform. The economic role of this policy is self-discovery in the face of uncertainty. To quote the oft-cited phrase from Deng Xiaoping in the early reform period, he stated that China's reform has been "crossing the river by feeling the stones." The political role is more pragmatic which emphasizes the vital role that experimentation can play in overcoming political resistance to reform.

Pragmatism, trial, and error, evidence-based policymaking, and experimentation with small-scale policy reforms that are later scaled up, are all key features of China's reforms. Most successful reforms have experienced pilot experiments and impact evaluations before being scaled up. Learning by experimentation is an important strategy when reformers face huge economic and political uncertainty. Due to doubt, it is difficult to judge which option is more feasible from the ex-ante point of view. In such cases, experimentation can be a useful tool to search for more information and for testing and updating prior hypotheses. Experiments yield information to help comprehend what works and what does not. Therefore, even failures can be helpful for the reason that they can help eliminate unfavorable options, as displayed by Luo (2008). The failure of Luo laissez-faire price system experiment in Hebei Province helped him come up with the idea of dual-track price reform system, which is a vital instance of an experiment where "Washington Consensus" wisdom was contradicted. The creation of the Shenzhen Special Economic Zones is another example. Shenzhen was a very small town by the border between Hong Kong and mainland China with a population of 30,000 people in the late 1970s. In 1979, Yuan Geng, director of the China Investment Promotion Bureau in Hong, proposed to set up a special industrial zone in the Shekou area of Shenzhen as a pilot for market reforms, taking advantage of the proximity to Hong Kong.

The state council quickly approved the proposal, earmarking 2.14 square kilometers for the zone and granting it special rights to test the applicability of the market economy in the zone. The industrial zone turned out to be an instant success. The investment from Hong Kong quickly filled in the limited land generating hundreds of thousands of jobs. After observing this success, in 1980 the Chinese government established a larger Shenzhen Special Zones, which encompasses 1,953 square kilometers, to carry out full fledges market reforms on a larger scale. This is the first citywide special economic zone in China.

${ }^{4}$ Heilmann 2008. Policy Experimentation in China’s Economic Rise. In: Studies in Comparative International Development, 43 (1): p. 1-26.

${ }^{5}$ Notably, although marginal reforms have some features of experimentation (like experiments, they maybe more reversible than wholesale reform, and they also promote learning), but they also have some distinguishing features relative to other experimental reforms. 
Experimentation can help control the possible disastrous consequence of the wrong choice. A vital point to note here is that, in the context of the emergence of randomized microeconomic experiments within development economic (Duflo, 2005), is that most China's experiments were not random. Specifically, experiments were frequently initiated in isolated poor areas. The Chinese government purposively initiated the household responsibility system as a pilot reform in many remote provinces so as to circumvent and minimize the potential costs of failure and lessen the political resistance.

Similarly, the Wenzhou area, which used to be a remote region in Zhejiang Province but is now one of the most dynamic regions in China, received special permission to be a pilot region for rural industrialization precisely because of its isolation at the time (Zhu, 2008). Under the special policy, Wenzhou made bold experiments in reforming town-village enterprises (TVEs) and legalizing private companies. After observing its success, most TVEs and small and medium SOEs were privatized nationwide by the late 1990s. Although such experiments were not so rigorously conducted as to include control groups, the pilots enable researchers and policymakers to observe what worked and what did not work. Another benefit of the Chinese method is that it involved an element of experimentation in macroeconomic reform, whereas contemporary randomized experiments are confined to microeconomic experiments (Rodrik 2008). Dual-track prices and special economic zones as displayed above are such examples. Such experimentation has been particularly vital in overcoming numerous major obstacles to effective reform in China, related to the nation's size, its diversity, and the history and structure of its hierarchical political system. For a large and diverse economy like China, it is very hard to derive a single one-size-fits-all blueprint for reform simply by applying textbook economic theories. Instead, trial and error processes can help discover local best practice. Though the impact of reform experiments varies between policy domains, China's experimentation-based policy process has been essential for redefining basic policy parameters.

\section{The issue of Pressure as a Catalyst Counts During Economic Reforms}

The "pressure" which stimulated the earliest reforms of the post-1978 period was the threat of economic crisis. After the Cultural Revolution (1966-1976) China was on the verge of collapse under the planned economy system. More than two-thirds of the people lived under one dollar per day (Ravallion and Chen, 2008). With stagnant agricultural growth and fast population growth, food was in short supply. At the onset of the reform, it seemed China faced extremely high barriers to escaping the low-level equilibrium trap where poverty persisted. Nevertheless, one of the architects of China's rural reform was the crisis, which triggers reforms. After the end of the Cultural Revolution, 
most of the top leaders and the masses realized that the planned system was not a viable option anymore, even if there was still uncertainty and argument as for how next to proceed. Under this situation, Chinese top leaders were more willing to listen to diverse views and permit open policy debate. In other words, the crisis offered would-be reformers with a window of opportunity to push fresh agendas. Important reforms do not come automatically and require policymakers to "seize the day" in a timely fashion.

China's joining the World Trade Organization (WTO) was one instance of the use of an external pressure to invoke and lock in reform. In the 1990s, banking reform met huge resistance for the reason that State banks did not want to give up their monopoly position. Several local governments also opposed the reform because they were afraid of losing their ability to direct credit, which made it very hard for State banks to really operate as commercial banks. Largely as a means of forcing further reforms in the banking and other key sectors, the top leaders made a bold move to enter China into the WTO. Although the WTO gave domestic banks few years window protection, in the end, most of the barriers to entry in the banking sector had to be removed such that State banks were eventually forced to compete on a level playing field. By employing external pressure from the WTO accession the government was able to induce a series of reforms within State banks. Although not complete, most Chinese banks have shed off bad loans, many major state banks have listed their stocks in overseas markets and are subject to the scrutinizing of international financial markets, and local bank branches now find it much easier to refuse loans to local officials. Therefore, the use of external pressure largely attained its implicit objectives. This section was concluded noting that all these explanations are highly compatible and complementary with each other and that together they comprise a compelling and holistic clarification of China's miracle.

\section{The Evolution of China's African Policy}

This first part of chapter three debates the evolution of China's African policy from the founding of novel China to the contemporary period, by means of three turning points: the 'Five Principles of Peaceful Coexistence in the Bandung Conference in 1955, the 'Four Principles of Chinese Cooperation with Africa' in 1982, and a 'Fresh Strategic Cooperation' in 2006.

\section{'Five Principles of Peaceful Coexistence' in the Bandung (Asian-African Conference) Conference in 1955}

The relationship between China and Africa can be traced back to over six centuries ago. In 1415, the Chinese explorers Zheng He visited the East African Coast and brought back to China shiploads of Chinese commodities. He reached four times the eastern coast of Africa, where current Tanzania, Kenya, 
and Somalia are located. Zheng He and his fleet introduced tea, porcelain, silk and advanced technology to the visited regions. What Zheng He took away from Africa was only a giraffe. During his visit, he was able to help extend the influence of China in Africa. But the interaction in modern time started from Bandung Conference held in the year 1955, which was broadly regarded as a seminal event in Sino-African history. The Bandung conference in Indonesia was considered pivotal in defining a new era of China-Africa cooperation. The conference was anticipated to bolster economic and cultural cooperation of both parties and promoted the anti-imperialist and anti-colonial struggle. The conference was attended by representatives of the twenty-nine Asian and African nations. It marked a decisive and crucial change in China relations with Africa. Of the twenty-nine nations that participated in the conference, six were from African nations, such as Libya, Egypt, Ethiopia, Liberia, and soon to be independent then Sudan and Ghana. The Chinese delegation met with several representatives of numerous African liberation movements who attended as observers. During the conference, the former Premier Zhou Enlai use the opportunity to denounce imperialism and colonialism in Africa and pledge support for the independence movement in Algeria, Morocco, and Tunisia.

Premier Zhou Enlai presented the Five Principle of 'Peaceful Coexistence', which covered mutual respect for sovereignty and territorial integrity; mutual nonaggression; non-interference in each other's internal affairs; equality and mutual benefit; and peaceful coexistence (Looy, 2006). The attainment of great diplomatic success followed the conference augmented China's interests in Africa. ${ }^{6}$ Premier Zhou Enlai in 1963 embarked on his first ten-country tour of Africa to promote the second-Africa conference. Although few agreed on the need for the second meeting, during his visit to Ghana in 1964, he proposed the Eight Principles that were designed to guide China's engagement with African nations. ${ }^{7}$ These principles obviously explained the Chinese intention to support African nations by the policy of economic and technical assistance. The assistance is to support African nations to gradually attain self-reliance,

\footnotetext{
${ }^{6}$ Followed the conference, political interactions were built between China and some African countries, including Egypt, Sudan, and Tunisia at the end of 1950s, Mali, Ghana, Somalia, Uganda, Kenya at the beginning of 1960s.

${ }^{7}$ The eight are: 1 . Chinese government have persistently been providing assistance to foreign countries according to the principles of equality and mutual benefit, never regard the assistance as the grant by one sided...... 2. While providing foreign aid, Chinese government strictly respects the sovereignty of recipient countries, no strings attached and no privilege required. 3 . in order to relief the burden of recipient countries, Chinese government provides economic aids in the way of interest free or low interest loan, the time limit of repayment could be delayed when it is needed. 4 . The purpose of Chinese government providing foreign aid is not to make recipient countries being dependent on China, but to help recipient countries gradually develop on the track of self-reliance and economic development independently. 5. For the projects constructed through China foreign aids, Chinese government does its best to make quick effects through smack investment. Thus, the governments of recipient countries could increase income and accumulate money. 6. Chinese government provides equipment and materials made in China with the best quality, and negotiate the price in accordance with the price of international market....7. While providing technical assistance, Chinese government assures to teach recipients to fully master this kind of technology. 8 . The experts who are dispatched by Chinese government to help recipient countries carrying out construction, should be paid as same as their own experts of recipient countries. They are required to not have any special requirement and enjoyment (Gountin, 2006).
} 
independent development, offer best-quality equipment and material of its own manufacturing. China significantly augmented its aid projects in the continent in the 1970s, as demonstrated in the number of African nations (See Table 1a \& 1b). Additionally, the principles displayed that the Chinese government offered the aid to African nations with and string attached, at least from an economic viewpoint. Some loans did not require repayment if African nations could not afford this. Nevertheless, for China's decision-makers, the aid diplomacy had both political and ideological purposes. On the ideological level, China appeared to give backing to any revolutionary movement against imperialism, including African revolutions. On the political level, the primary drive was to compete with Taiwan and then get African to support the People Republic of China (PRC) in global recognition and to compete with the Soviet Union in the African sphere.

Table 1a: Thirteen African Nations Receiving Chinese Aid in the 1960s

\begin{tabular}{lcc}
\hline Country & Aid Agreement Date & Amount (US\$ Million) \\
\hline Algeria & 1958 & 100 \\
Egypt & 1958 & 193 \\
Ghana & 1961 & 81 \\
Mali & 1961 & 148 \\
Somalia & 1963 & 220 \\
Tanzania & 1964 & 534 \\
Kenya & 1964 & 91 \\
Burundi & 1964 & 125 \\
Central African Republic & 1964 & 56 \\
Congo & 1964 & 205 \\
Uganda & 1965 & 77 \\
Mauritania & 1967 & 239 \\
Zambia & 1967 & 372 \\
\hline
\end{tabular}

Source: $\mathrm{Wu}, 2008$

Table 1b: Thirty African Nations Receiving Chinese Aid in the 1970s

\begin{tabular}{lcc}
\hline Country & Aid Agreement Date & Amount (US\$ Million) \\
\hline Sudan & 1970 & 230 \\
Equatorial Guinea & 1971 & 18.7 \\
Ethiopia & 1971 & 155 \\
Guinea & 1971 & 161 \\
Sierra Leone & 1971 & 94 \\
Togo & 1972 & 77 \\
Tunisia & 1972 & 97 \\
Benin & 1972 & 72 \\
Mauritius & 1972 & 48
\end{tabular}




$\begin{array}{lcc}\text { Nigeria } & 1972 & 3 \\ \text { Rwanda } & 1972 & 56 \\ \text { Burkina Faso } & 1973 & 92 \\ \text { Cameroon } & 1973 & 124 \\ \text { Chad } & 1973 & 77 \\ \text { Senegal } & 1973 & 108 \\ \text { Niger } & 1974 & 64.7 \\ \text { Gabon } & 1975 & 26 \\ \text { The Gambia } & 1975 & 36 \\ \text { Guinea-Bissau } & 1975 & 18 \\ \text { Mozambique } & 1975 & 116 \\ \text { São Tomé and Príncipe } & 1975 & 12 \\ \text { Botswana } & 1976 & 19.4 \\ \text { Comoros } & 1976 & 10.3 \\ \text { Morocco } & 1976 & 32 \\ \text { Cape Verde } & 1977 & 17.6 \\ \text { Liberia } & 1977 & 37.4 \\ \text { Seychelles } & 1978 & 8.1 \\ \text { Djibouti } & 1979 & 12.9\end{array}$

Source: $\mathrm{Wu}, 2008$

\section{Four Principles of Chinese Collaboration with Africa in 1982}

The success of China in Africa has strengthened the country's status as a global superpower. Also, Africa plays a significant role in the diplomatic jostling between the People's Republic of China (PRC) and the Republic of China in the United Nations. Out of the 76 overall votes backing the PRC taking over the Chinese seat from Taiwan in 1971, 26 votes came from African countries. ${ }^{8}$ This incident led Mao Zedong to claim that "it was our African brothers who carried us into the United Nations. After the most significant objective, the United Nation seat, was attained, a mutual diplomatic recognition between China and America was established. The less intensive global environment was mirrored in China's foreign policy so that economic growth and domestic reforms instead of revolutionary objectives dominated the policy agenda. In 1982, two messages were sent by the $12^{\text {th }}$ Communist Party Committee National Assembly that had implications for China's Africa policy: (i) China would pursue its independent foreign policy characterized with 'mutual benefits' in actual meaning; (ii) China would focus on domestic economic development (Li Anshan, 2007). Based on the 1982 trip to Africa, in line with these changes, the Prime Minister Zhao Ziyang provided an exclusively fresh 'Four Principles on SinoAfrican Economic and Technical Cooperation', which stressed on equality and mutual benefits, practical outcome, diversity in forms and common development (Onderco, 2007). ${ }^{9}$ There is a

\footnotetext{
8 "Marius Fransman, South African Deputy Minister of International Relations and Cooperation, Keynote Address to the Ambassadorial Forum on China-South Africa Diplomatic Relations at 15 Years”, Pretoria, South Africa, September $19,2013$.

${ }^{9}$ The Four Principles include: 1 . In carrying out economic and technological cooperation with African countries, China abides by the principles of unity and friendship, equality and mutual benefit, respects their sovereignty, does not interfere in their internal affairs, attaches no political conditions and asks for no privileges whatsoever. 2. In China's economic and technological cooperation with African countries, full play will be given to the strong points and potentials of both sides on the basis of their actual needs and possibilities, and efforts will be made to achieve good economic results with less investment, shorter construction cycle and quicker returns. 3. China's economic and technological cooperation with African countries takes a variety of forms suited to the specific conditions, such as offering technical services, training technical and management personnel, engaging in scientific and technological exchanges, undertaking construction projects, entering into cooperative production and joint ventures. ......4. The purpose of China's economic and technological cooperation with African countries is to contribute to the enhancement of the self-
} 
notable dissimilarity when comparing the Four Principles of the 1980s to the Eight Principles in the 1960s. The dissimilarity was that China asked for mutual promotion of the two economies, as displayed in principle 2 and 4. Certainly, economic aid between the poor nations could not be sustained in the long term if it was only limited to a one-way flow. By that time, China was no longer interested in sustaining its position as an influential actor in Africa but was eager to develop own economic capability. In other words, Africa lost its significance in China's eyes and was marginalized as the Chinese concentration moved to its own modernization. In the era when the Chinese itself relied on external funds, there was little that the Chinese could offer for African nations.

\section{A Fresh Strategic Cooperation in 2006}

There was a pause in China-Africa relationship that lasted until Tiananmen Square event of 1989. The turmoil saw China faced with serious global isolation and Western sanction. It was six African nations (Zambia, Zimbabwe, Mozambique, Lesotho, and Botswana) that stepped up and saved China from the quagmire. In appreciation for the tremendous political favor, China has reciprocated by making Africa the first destination of Chinese foreign minister visit. So, after the turmoil, China intended to focus its diplomacy on the developed nations, but China was confronted with harsh condemnation of human rights and punishment exemplified by political isolation and economic sanction. These made the Chinese government aware of the insurmountable value divergence between itself and Western countries. For that reason, the only strategy for China was to look back and strengthen its ties with developing nations as a defensive mechanism. This meant a reappraisal of the role of the third world nations, including ASEAN nations and African nations, which expressed their understanding towards China's action in handling this internal problem. As part of an effort seeking political support, China's top leaders made high-level visits to Africa in 1979 (Li Xiannian), 1982-1983 (Zhao Ziyang), 1984, 1997, 2001 (Li Peng), 1992 (Yang Shangkun), 1996, 2000, and 2002 (Jiang Zemin), and 2002 (Zhu Rongji- twice). Vice-premier and the Chinese Foreign Minister, Qian Qichen visited over thirty-six African countries between 1990 and 1998. The flurry of activity we see today has deep roots and therefore laid the foundation for an intense diplomacy that continues unabated today. The trip highlighted China's intention in looking for potential political assistance from African nations. During 1996 national visit, President Jiang Zemin suggested building a long-term and stable Sino-African cooperation of all-round cooperation and relationship geared towards the $21^{\text {st }}$ century.

In 2006, the Chinese government specifically published a vital white paper, China's African Policy, which was the first Africa policy paper of its kind in China's diplomatic history with African nations. The white paper explains Africa's strategic significance to the Chinese, which embodied China's long-term plans. Over the past decade, the policy has been carried out fully and effectively, playing a significant guiding role in the all-round development of China-Africa relations (Li Anshan, 2007). Through the white paper, the Chinese government showcase to the world that the goal of China's Africa policy is based on establishing and developing comprehensive and new kind of strategic and cooperative China-Africa partnership and consolidating and bolstering the community of shared future between China and Africa on the basis of advancing the fundamental interests of both parties. The white paper captures the Chinese government's attempt to further clarify China's determination and goodwill to develop friendly and cooperative relations with Africa and expound the new vision, approach and measures of China's Africa policy under the new circumstances with the aim of guiding the multi-faceted exchanges, cooperation and strategic relationship between China and Africa in the years to come. The Chinese government

reliant capabilities of both sides and promote the growth of the respective national economies by complementing and helping each other. (Brautigam, 1998:49-50). 
repeatedly addresses the issue of mutual benefit under the framework of strategic cooperation. Apparently, the gain the Chinese government is referring to does not purely refer to the political benefits in 1955-1978 or the economic interests during 1978-1989. Instead, the Chinese government established strategic objectives via pragmatic pursuits, including cultural exchanges political cooperation, and economic interactions as displayed in the white paper.

\subsection{The Application of Eidenfalk's Model of Foreign Policy Change}

According to Eidenfalk, he asserted that any analysis of foreign policy transformation has to be balanced in the manner in which it considers factors that affect or influences changes in foreign policy. Speaking of factors influencing change, in the section on factors influencing China's foreign policy change, domestic and international factors that is to say the role of public opinion, business interests, government bureaucracy, China's competition with the West and the socializing effect of being integrated into the community of states (UN), are taken into consideration. These factors do not operate individually instead influence one another. For example, demands from commercial interests and snowballing nationalism compel the government to shorten bureaucratic processes and hasten foreign policy changes. The impact of these domestic factors on foreign policy is not significant given the style of governance in China that is to say civilians concern do not affect the policymaking process. On the other hand, factors emanating from the international system wield great influence and have a higher propensity to inspire change. Such influence derives from the fact that, they affect the identity or image of the nation. In this situation, the steepness of China's foreign policy bureaucracy, public opinion, increasing intentions of individual and large cooperation's intentions to extend their operations to Africa are all represented by China's existing foreign policy. A change in the structure of the international system, brought about by security threats in the form of civil war, refugees, terrorism, and poverty, require states immediate action, mandated by the collective action element that defines characteristics of expected state behaviour in the contemporary international system.

Furthermore, defying these anticipation mandates criticism by other nations. The Chinese government has been a recipient of such critics, which have affected the country's image as a potential worldwide leader. In addressing such negative perceptions on its image, The Chinese government recently shifted the country's form of policy from non-interventionist stance to a proactive one. This close interaction and blending of such factors can influence foreign policy transformation as well as determine the degree to which foreign policy changes. From the examples of policy change discussed initially and drawing from the earlier discussion and differentiation of change and a shift in foreign policy, China change its foreign policy from disbursing aid in form of gifts to a strategy that returns political and economic advantage back to Beijing. This move did not significantly diverge from China's foreign policy. Instead, it only changed the objectives and goals within the same aid policy framework. The move from noninterference to active engagement is regarded as a shift and not a change in China's foreign policy. This becomes an issue of categorization. For example, the non-interference principle is codified in the five principles guiding China's international conduct but active engagement is not. Since the two are not classified in the same category, the movement cannot be regarded as a transformation but a complete shift in the Chinese government policy from one category to the other.

\subsection{The Changes in China's Foreign Policy Towards Africa}

As stated in the previous chapter, the Chinese strategic rise brought about the change in China's foreign policy. Several experts subscribe to the notion of change in foreign policy among them Herman (1990) who argues that 'change is a pervasive quality of government's foreign policy. 
But irrespective of Herman's views and that of other experts, foreign policy surveys have paid less attention to the possibility of change in favor of stability and continuity in foreign policy. It was only after the 1980s that global development for example, the European Union, the demise of the Soviet Union, the spread of democracy as an ordering principle, and the rise of China, coupled with the necessity to improve theories that led experts to start displaying augmented interest in why, when, and how states need to reorient their foreign policies. This part of the paper proceeds by initially presenting a brief discussion on one of the most neglected terms in foreign policy analysis, foreign policy change (Huxsoll, 2003). Various theoretical models of foreign policy change have been constructed by diverse experts (e.g. Goldmann 1982, Holsti 1982, Hallenberg 1984 Hermann 1990, Carlsnaes 1992 \& 1993, Rosati et al 1994, Jian 1996, Oldfield 1998, Ataman 1999, Gustavsson 1998 \& 1999, Kleistra \& Mayer 2001). However, each of these models either ignores or does not deal adequately with certain factors, making them insufficient to fully explain foreign policy change in relation to China's cooperation with African nations. Based on that, this section will focus on the model presented by Joakim Eidenfalk (2006) which is one of the most relevant when applied to China's relations with Africa. Also, making use of the influencing factors, this part of the paper analyses the diverse examples in which China has instituted changes in her foreign policy towards Africa. The analysis is presented within the context of Joakim Eidenfalk's model. Joakim Eidenfalk (2006) sufficiently captures and advances the key debate on China's changing policy towards Africa, in the extent of change model.

This model is most appropriate to analyze China-Africa cooperation as a result of its balanced approach when bearing in mind factors and actors in the policymaking procedure. Joakim Eidenfalk encompassed factors such as the role of leaders, the media, public opinion, the global and regional dimension in opening the windows of opportunity. All these factors were either previously side-lined or no significant impacts in other theoretical models. The ultimate objective of any theoretical model is to break down a given phenomenon into simple and understandable terms. In like manner, by incorporating all possible factors in Eidenfalk (2006) model and made it relatively easy to explain the reason foreign policy changes and clarify that change is not influenced by a single factor but an eclectic array of factors. Bearing in mind these factors, individually, it also bolsters our capacity to comprehend the reason nations change their foreign policies. Joakim Eidenfalk also warns against the tendency of merely stating the factors that influence the policy procedure, stressing, instead, the significance of the interactions and influence that these factors have on each other as well as with the actors in the policy procedure in comprehending the reason foreign policies change and the accompanying policy effects. Joakim Eidenfalk called his model the 'extent of change' in that it 'looks at the scope, domain, and effects of change, thereby measuring the extent of change.' Unlike other models Joakim Eidenfalk's focus on the dimensions and aspects of change itself.' In another scenario, Doeser (2013) debates that foreign policy change can also be as a result of a single initiative by the state leaders. The author asserts that this kind of policy change 'is the result of an alternative policymaker, often the head of government, who imposes his own vision of the basic redirection necessary in foreign policy. It is the leaders' determination and vision, which is vital in determining changes in foreign policy.

Speaking of leader, Deng Xiaoping transformation of China from the ideological and confrontation conduct during Mao's era, to emphasis more on economic openness, integration and friendly partnership, in some way fits Doeser's conception of leader motivated foreign policy change (Botchway, 2011). However, the timeframe in which Deng's changes happened to fallout of the scope of this study. One of the greatest challenges and concern of Xi Jinping in Africa is security issues for China's citizens and investment. The challenges create a window of 
opportunity that the Chinese government could explore, but Xi Jinping's personal initiative in this regard is yet to be determined. Since Xi Jinping inauguration, China has adopted a more assertive stance in Africa by engaging directly in diplomatic negotiations and helping to deploy combat troops in conflict zones (Sun, 2014). The preceding part of this paper presents the most vital discussion of this paper, especially the discussion on the actual changes in China policies towards Africa. In order to comprehend China's engagement in Africa, we have to understand the transformation of the strategy following the Chinese opening up in 1978, and what brought about the change of its foreign policy, especially China's Africa policy.

China's approach to Africa has already shifted from providing political support and the dominance of ideological considerations to sort of economic diplomacy that is focused on facilitating win-win cooperation through the market economy. Once referred to as a "hopeless continent," Africa has undergone structural economic adjustments and encouraged privatization over the past decade, as opposed to the past practices of relying heavily on policy adjustments and foreign aid. Compared with Western nations, one sees that the Chinese foreign policy towards Africa is relatively more unique and suitable. This is because Chinese and African industrial chains and economies have proven to be highly complementary. As one of the world's vital centers for industrial productions, China's economic development is currently in the midst of transition and needs Africa's energy and resources. Similarly, China can offer African nations with low-cost industrial goods and civil engineering teams. The interconnection of these industrial chains will only be able to continue developing in a politically stable environment. It will be difficult for the Western nations, especially, European nations and the United States to accomplish this, for the reason that their levels of industrial development are comparatively high. African markets do not strongly favor cutting-edge technological goods, while Western nations are not especially interested in making investments in the small risky market.

So, Africa and China's closely integrated economic development is not merely a result of the policies by either party. This development is more a result of the connections and interactions between China and Africa which has led to the possibility of the global industrial chains as well as the economic diplomacy resulting from the changing China's Africa policy. According to Anshan (2007), the author asserts that two factors caused the transformation: the transformation of the Chinese strategic thinking (emphasis is shifted to the internal economy) and the judgement of the international situation (peace and development, instead of revolution and war turned out to be the major issues). Two significant changes followed the transformation; the initial argument is based on the fact that China foreign policy has changed from ideological considerations to economic diplomacy and the other argument is that there is a shift toward a new type of international relations from a single form of aid to multiple channels of cooperation. All these changes are summed up to determine the degree of change needed by the modified Joakim Eidenfalk's model of foreign policy change. The next chapter will look at these two significant changes that followed the Chinese transformation regarding China's Africa policy as well as what it means for African nations.

\section{The Two Significant Signs of Changes in China's Africa Policy and What It Means for Africa}

\subsection{From Ideological Considerations to Economic Diplomacy}

According to Anshan (2007), the author acknowledges the close relationship between China's foreign policy and its ideology. Actually, China's ideology works as the guiding principle and cornerstone of how the Chinese interact with other nations, especially African nations. This study argues that if ideology, as the guiding principle of foreign policy evolves, then foreign 
policy will follow as well. As a result, the connection between these two factors presents one of the most distinguished and important instances in which China has shifted from the way it normally interacts and engages African nations. The Chinese relations with African nations were strongly driven by ideological deliberation before the 1980s, particularly directed towards curtailing Soviet expansionism, European colonialism and American imperialism in Africa. It all started after the founding of People Republic of China, China initially adopted the one-sided policy of pro-USSR and anti-U.S. in the 1950s, then the policy of double-attack of antiimperialism and anti-revisionism (1960s), and later the policy of alliance with the United States while opposition to USSR in the 1970s (Anshan, 2007). During this period, the focus of China's foreign policy towards Africa was that the Chinese should stand at the frontier of anticolonialism, anti-imperialism, and anti-revisionism. Following such commitment, the Chinese government sponsored and assisted radical African liberation parties with rhetorical financial and military training and equipment (Shinn \& Eisenman, 2012). According to Mashingaidze, these parties include South-West People's Organization (SWAPO) in Namibia, the African National Congress (ANC) in South Africa (Worden, 1986), the Mozambique Liberation Front (FRELIMO) in Mozambique, the African Party for the Independence of Guinea and Cape Verde (PAIGC) in Guinea-Bissau, Zimbabwe African National Union ZANU in Rhodesia (Zimbabwe) amongst several other (Mashingaidze, 2016). The Chinese continent-wide coverage displays the level of commitment the country had towards realizing its ideology and more significantly, the attainment of the goals and objectives that mandated the Chinese presence in the continent of Africa.

Li Anshan asserts that against former instances in the 1960s in which the Chinese Communist Party refused to have contact with non-communist political parties in Africa. However, the 1982 Chinese Communists Party conference ushered a fresh plan for engaging other progressive political parties. The plan comprises of the guiding principles like the mutual respect for each other's territorial integrity and sovereignty, mutual non-aggression, mutual non-interference in each other's internal affairs and equality and cooperation for mutual benefit, which are principles driven by the 1954 principles of peaceful co-existence (Anshan, 2007). The principles originally represented a vision of international relations that was highly principled and not based on realism necessarily. In line with Li Anshan claim, Mohan \& Power (2008) shared a similar opinion that Enlai and Mao period paid special attention to ideology and applied ideology in establishing the principles that were to govern partnership and provision of development assistance to developing nations. The Chinese ideology cocooned the ideas of independence and nationalism, ethical values that were meant to bolster the image of the Chinese in Africa while simultaneously demonizing Western nations and their ideologies of domination based on imperialism and colonialism. The positive trends in the manner in which the Chinese government engaged African nations were no longer motivated by ideology as stated earlier on; this shift from ideology reshapes China's Africa cooperation. This change can be interpreted this way: (i) the first aspect focus on the partnership of interaction that is not confined to the ruling parties alone, but also to the non-ruling parties; (ii) the cooperation between African nations and the Chinese government is no longer based on socialist ideology, but now comprises of all parties irrespective of their ideological perspectives; (iii) the cooperation between Chinese government and African leaders is no longer based on party politics but now encompass interaction between sub-national players like the Ministries of Finance, Trade, Foreign affairs, individual provinces, Non-governmental Organizations (NGOs), and multinational cooperation's (Mashingaidze, 2016).

In essence, the Chinese foreign policy towards Africa changed from the Cold war ideology to a more pragmatic and classical pursuit of economic self-interest in the form of access to raw 
materials and the construction of spheres of influence via military assistance, investment, infrastructure financing, building capacity, and trade. The establishment of the Forum on China-Africa Cooperation (FOCAC) signifies a mixture of all these pragmatic considerations and also, the several pledges made by the Chinese government indicates the Chinese commitments to this fresh plan. The shift from ideological emphasis also altered the strategy through which the Chinese sought cooperation with its African counterparts. The Chinese government slowly altered its strategies by greatly strengthening its interaction with African parties, and the Chinese government relations with others is characterized following a shift from emphasis to Neutrality, from confrontation to partnership, from revolution to economic development, and from isolation to worldwide engagement (Mohan \& Power, 2008). The transition has helped to strengthen China-Africa cooperation. High-level visits have been frequent and numerous talks have been held on how China and Africa should assist each other economically to support each other in the regional and global affairs. The opening up of political and economic relations has significantly augmented China-Africa cooperation, which also turned out to be a significant component in China's African policy.

\section{A Shift Toward a New Type of International Relations: From a Single Form of Aid to Multiple Channels of Cooperation}

China's Africa foreign policy shift reflects new realities for African nations. The new reality has shifted China's Africa policy from political contact to exchange through multiple channels of cooperation. Africa is one of China's diplomatic 'new frontiers' as exemplified by new Chinese leader Xi Jinping's maiden foreign trip to Africa in 2013. For that reason, the Chinese primary concern behind China's relations with African nations is the adherence and realization of the five principles guiding China's foreign policy. However, out of the five principles, the Chinese government actions, judge via nations visits and monetary commitments, mutual economic development ranks higher than subsequent commitments to eradicate poverty and make sure independence in African nations become a reality. This paper argues that China's foreign policy towards African nations has changed in two phases that is to say it has shifted from ideological considerations to economic diplomacy and from a single form of aid to multiple channels of cooperation. In order to demonstrate how this form of collaboration transformed, the paper presents the discussion of the different phases in the next paragraphs.

As stated by the 2011 White Paper on China's foreign assistance, China is a developing nation. Over the years, while focusing on its own development, China has been offering assistance to the best of its capability to other developing nations with economic difficulties and fulfilling its due global obligations. In the 1950s, soon after the founding of the People's Republic of China, although it was short of capitals and resources, China started to offer economic assistance and technical aid to other nations, and gradually extended the scope of such assistance. Since China adopted the reform and opening-up policies in the late 1970s, its economy has been developing speedily, with the overall national strength growing notably. The purpose of China's assistance during this period was to 'strengthen (the recipient nation's) self-development capacity, enrich and improve their people's livelihood, and promote their economic growth and social headway.' The 1964 declaration of the Eight Principles for Economic Assistance to other nations offered the premises on which the Chinese government offered foreign assistance to other nations. The core principles of providing foreign assistance comprise of the guiding principles like the mutual respect for each other's territorial integrity and sovereignty, mutual nonaggression, mutual non-interference in each other's internal affairs and equality and cooperation for mutual benefit. After being carried to the United Nation by African nations, the Chinese government augmented its aid to Africa. A good example of China's commitment was the completion of the iconic construction of the Tanzania-Zambia Railway (TAZARA) (also 
known as Tansa Tie Lu); a symbol of China-Africa relations. The railway 50 anniversary was commemorated in September 2017; there is also high impact infrastructural development projects in Africa like the mega-projects inaugurated on May 31, 2017 - the Standard Gauge Railway (SGR). Another good instance in terms of assisting African nations was the support the Chinese government rendered to African political parties during their liberation struggles. Through that support, Egypt turned out to be the first African nations in 1956 to receive this type of support from China (FOCAC, 2015).

As stated by Li Anshan (2007), the author asserts that African leaders proposed that traditional assistance was less efficient in ensuring self-sufficiency in Africa. For that reason, African leaders proposed and encouraged external donors to offer development aid and foreign investment that would bolster developing productivity in Africa. Following this, the Chinese government started reorienting its aid policies by trying a fresh form of assistance. For example, after realizing Africans incompetency to operate and maintain projects it had funded under the total present aid policy, the Chinese government turned out to hands-on in the operations and training of staff at the Segu Textile Plant in Mali and Aniye Sugar Plant in Togo (Mashingaidze, 2016). The issue of capacity building schemes and economic exchange programmes were meant to revolutionize the effectiveness of China's assistance as well as equip African leaders and professionals with the necessary technological management skills and experience necessary to initiate and manage development in their own nations. As stated earlier, China as a developing nation and the country identifies with African nations and considers itself as a friend to other developing nations, therefore, China is in a better position to demonstrate to its African counterparts how to successfully develop their economies. In other to proof this and strengthen its relations with African nations, China organized seminars in which the country trained African professionals as well as capacity building for African officials. A good example was the 2003 Seminar on Economic Reform and Development Strategies that attracted twenty-two officials from sixteen African nations and seven from the African Development Bank (Anshan, 2007).

Additionally, China has helped to accelerate the development of African human resources. In recent years, the Chinese government has set up an African Human Resources Development Fund. By offering government scholarships to students, China has helped develop education and human resources in African countries. Between 2008 and 2011, there were 252 trainees from 40 different African nations participating in these programs (MOE, 2012). Between 2000 and 2012, it was estimated that no less than 45,000 African professionals took part in the short-term training in China; these programs were funded by the African Human Resources Development Foundation (King, 2013). Also, from 2010 to 2012, China ran training sessions with an overall capacity of 27,318 trainees for officials and technical personnel from 54 African nations. The training sessions covered the field of foreign affairs, agriculture, forestry, animal husbandry, fishing, medicine, manufacturing, healthcare, inspection and quarantine, climate change, industry, public management, energy, and social security (Shoko, 2016). Also, Chinese medical teams, agricultural experts, and enterprises situated in Africa have trained local people in an effort to enhance local technological capabilities and upgrading China-Africa cooperation in science and technology (Tambo et al, 2016). In the $5^{\text {th }}$ Ministerial Conference of the Forum on China-Africa Cooperation, the Chinese government announced "African Talents Program" to train 30,000 African professionals in various sectors such as agriculture, industry, economic infrastructure, public facilities, education and medical and healthcare, with the intent on improving African nations' industrial and agricultural productivity, laying a solid foundation for their economic and social development, and improving basic education and healthcare. 
China's aid policy in Africa underwent major reforms between 1994 and 1995. These were effected in three main ways: (i) new instruments that connected aid, trade, and investment between China and Africa were introduced and implemented; (ii) programmes that combined foreign aid with economic cooperation were developed and funded, and (iii) the Chinese redefined their portfolio of tools to assist domestic restructuring. Also, the second summit of the Forum on China-Africa Cooperation in Johannesburg in December 2015, Chinese President Xi Jinping announced the "10 major plans" to boost China-African cooperation between 2015-2018. This includes establishing a number of regional vocational hubs and several so-called capacitybuilding colleges" to address the continent's dearth of skilled workers. This will train 200,000 technicians and offer 40,000 African students with chances for professional training (FOCAC, 2012; MOFCOM, 2015; Shoko, 2016). Based on these increased numbers, the Chinese government placed particular emphasis on the 'quality' of its training

Also, China's investment in Africa is having a positive impact on research; one example to support this fact is China's African Talent program. The program has trained 30,000 Africans in various fields as well as given 66 African researchers the chance to do post-doctoral research in China and donated 150,000 Yuan $(\$ 24,000)$ worth of research equipment to each of the 24 researchers who had returned to their home countries to work upon completing their joint research projects in China (Tambo et al., 2016). Another comprehensive example of the change in China's assistance towards the African nation is evident in how the Chinese government now applies a win-win situation when offering assistance to African nations instead of the traditional presents (Anshan, 2007). A win-win strategy entails the realization of the need to derive mutual benefits from cooperation. For that reason, the institutionalization of FOCAC meetings was a way of officializing, operationalizing and executing the win-win cooperation between both parties. Furthermore, China pays more attention to investing in "hardware projects" such as roads, bridges, and other infrastructure, which deliver tangible benefits to the local economy of numerous African nations. The Export-Import Bank of China (China Eximbank), founded in 1994, plays an important role in offering loan support to these infrastructure projects. China has provided almost 900 aid projects to African nations since 1956. The aid includes assistance supporting textiles factories, hydropower stations, stadiums, hospitals, and schools. Although China assists African nations with infrastructure which Africa needs in terms of closing the infrastructure deficit, these projects do not come cheap or free. They are funded with Chinese loan from China's largest financier of African loans - China's Export-Import (EXIM) Bank. The billions of dollars China commits to Africa are repayable, long-term loans. From 2000 to 2015, China Eximbank contributed US\$63 billion in loans to Africa. largely aimed at road, railroad, airport and harbor construction. The top Africa nation recipients of China Eximbank financing from 2000-2015 are Ethiopia at US\$7.2 billion, Angola at US\$6.9 billion, and Kenya at US\$6.3 billion (EOM, et al, 2017) (see Figure 3). The largest China Eximbank commitment was a US\$3.8 billion loan (in two tranches) in 2014 to build the Standard Gauge Railway from Mombasa to Nairobi in Kenya. The second largest loan was a commitment of US $\$ 3$ billion (split between Ethiopia and Djibouti) in 2013 for the construction of the Addis Ababa-Djibouti Railway (EOM, et al, 2017). 
Figure 3 : China Exim Bank Loans to Africa, by Country. 2000-2015

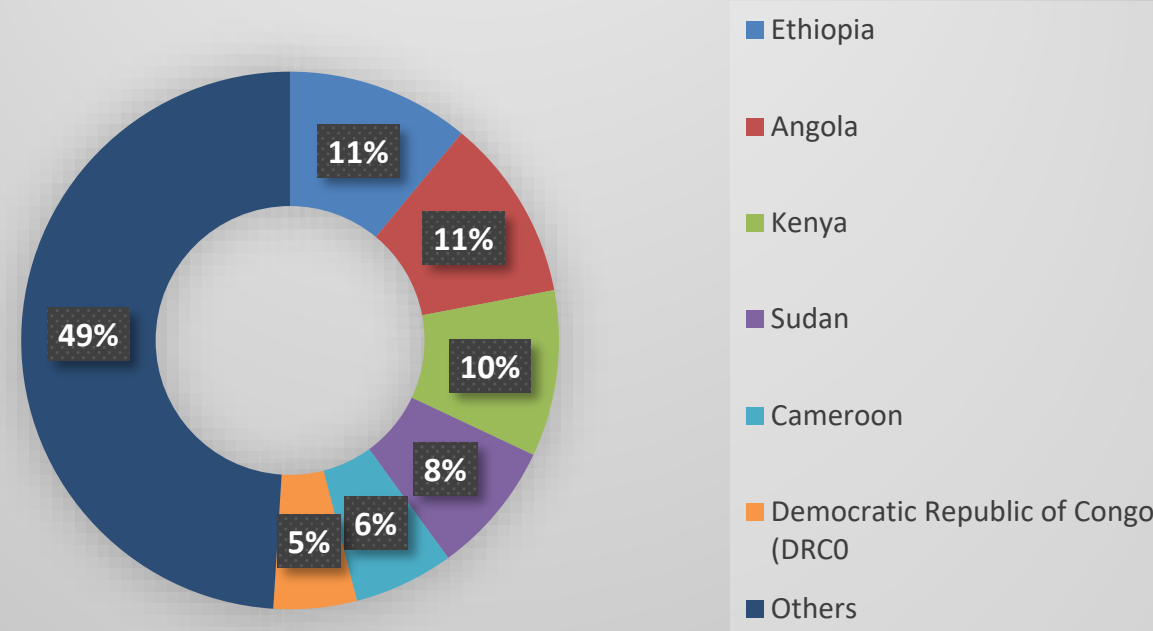

Source: EOM et al, 2017

On the part of the trade, China surpassed the United States to become Africa's largest trade partner in 2009. The trade data portrays an obvious picture for mutually beneficial cooperation. Africa China trade figure augmented remarkably from US $\$ 10$ billion in 2000 soaring to US $\$ 18.5$ billion by 2003 reaching US $\$ 198.5$ billion in 2012; in 2014, the figure grew to $\$ 220$ billion (MOFCOM, 2015). However, the developing tale of increase in trade between China and Africa changed in 2015; from January to October 2015 the trade between both parties' decrease to $\$ 147.6$ billion; the trade volume decreased by 18 per cent year-on-year, but in 2016, the trade volume increases to $\$ 149.2$ billion making China Africa's largest trading partner for the eighth consecutive years (MOFA, 2017) (see figure 4) However, the discourses on trade relations at times propose that the Chinese stands to profit more, as the stronger power in this partnership, such texts shy away from quantifying the profits accruing to African nations in terms of sector development, job opportunities, capacity building and access to resources (Mashingaidze, 2016). In addition, the impact of upsurges in trade figures is highest in Africa compared to China. 


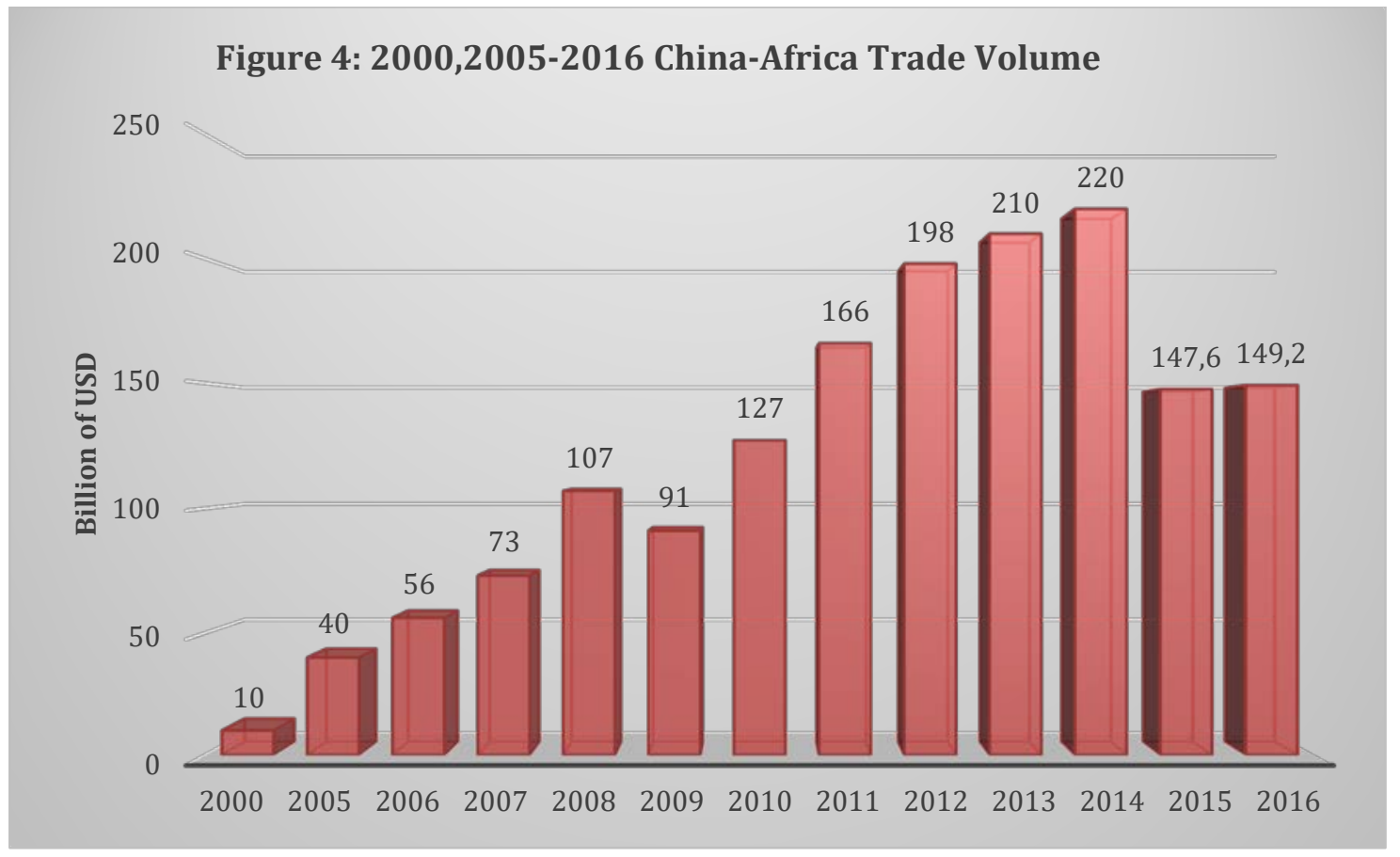

Source: Ehizuelen, 2015, MOFCOM, 2015, MOFA, 2017

\section{Conclusion}

Over the past three decades of reform, China has successfully followed a resource-intensive and outward-oriented economic development model. Since the execution of reform policies, China has progressively embraced the principles of a market-based economy. It transformed its economic structure from a state dominated, self-reliant economy towards a dynamic privatesector-led open economy. China's rapid economic growth over the last few decades has largely been driven by capital accumulation and integration into the global economy through FDI and trade. China has successfully exploited its comparative advantage in abundant cheap labour and specialized in the production of labour intensive manufacturing goods. Improvements in technological efficiency, better reallocation of resources across sectors and structural transformation have substantially raised its productivity.

Generally, the argument in this paper has set the ball rolling for an interesting and intuitive debate on China's foreign policy. Notably, the Chinese re-emergence globally and particularly in Africa has been firmly premised on a strong ideological impetus that pushes for the establishment of a fresh global political dispensation. Ideologically, the Chinese perceive the prevalence of peace both regionally and deliberately as vital in the achievement of this novel dispensation. As a result, it highlighted the issue of peaceful development and co-existence as the basis of its conduct internationally. The five principles of mutual respect for sovereignty and territorial integrity, mutual non-aggression, non-interference in each other's internal affairs, equality and mutual benefit, and peaceful coexistence recognizes specific matters and areas in which the Chinese government foreign policy would identify and implement a plan of penetrating and soliciting partnerships with countries in Africa.

The paper identified and conceptualized the notion of change in a country foreign policy as a significant and central anchor of this survey. The paper presented a brief discussion on Joakim Eidenfalk (2006) model in analyzing foreign policy change as well as the various matters that influence changes in foreign policy. Joakim Eidenfalk's model is recognized as the most 
appropriate model for analyzing changes in China's Africa policy as a result of its balanced viewpoint and its emphasis on bringing out the degree of change. From this model, domestic and international factors that influence the policy changes are explored. The survey established that worldwide more than domestic factors, in China's circumstances place more demands on the evolution of its foreign policy. The constructivist idea of socialization and structural changes in the global system has contributed more towards China's global behavior. As a result, China's foreign policy towards Africa has transformed from offering aid as gifts to aid provided on a win-win basis. Also, the transformation is apparent in the Chinese government assertive conduct in Africa and in how it has shifted from ideological considerations towards pragmatic considerations.

\section{References}

Anshan Li (2007). “Transformation of China's African Policy: When, Why, and What, Paper Presented at China-World Conference "Made in China vs. Made by Chinese: Global Identities of Chinese Business," University of Durham.

Ataman, M. (1999). An Integrated Approach to Foreign Policy Change: Explaining Changes in Turkish Foreign Policy in the 1980s, University of Kentucky, Doctoral Dissertation.

Brautigam Deborah. (1998), Chinese Aid and African Development, Palgrave Macmillan Publishing Limited UK, Pp.49-50

Botchway, M. N. (2011). Natural Resource Investment and Africa's Development, United Kingdom, Edward Elgar Publishing Limited.

Cheung, Steven N.S., (2008). "The Economic System of China," Paper Presented at the 2008 Chicago Conference on China's Transformation, July 14-18.

Carlsnaes, W. (1992). The Agency-Structure Problem in Foreign Policy Analysis, International Studies Quarterly, 36, pp. 245-70, 1992.

Carlsnaes, W. (1993) On Analyzing the Dynamics of Foreign Policy Change: A Critique and Reconceptualization, Cooperation and Conflict, 28-1, pp. 5-30.

Doeser F (2013) Leader-driven foreign-policy change: Denmark and the Persian Gulf War. International Political Science Review 34(5): 582-597.

Duflo, Esther, (2005). "Field Experiments in Development Economics." Bureau for Research in Economic Analysis of Development Policy Paper No. 12.

Easterly, William R. (2002). “The Elusive Quest for Growth: Economists' Adventures and Misadventures in the Tropics", Cambridge: MIT Press.

Ehizuelen Michael M.O (2015). The Impact of China's Economic Activities in Africa on Economic Growth of African Countries. Bangladesh Development Studies Vol. 38(4): pp.51.

Eidenfalk, J. (2006). “Towards a New Model of Foreign Policy Change, A Paper Presented to the Australasian Political Studies Association Conference, University of Newcastle.

EOM J., Hwang J., Atkins L., Chen Y., \& Zhou, S. (2017). The United States and China in Africa: What the Data say? Policy Brief, No18. China-Africa Research Initiative (CARI) at the John Hopkins University School of Advanced International Studies (SAIS) in Washington, D.C. 
Fan, Shenggen, (1991) "Effects of Technological Change and Institutional Reform on Production and Growth in Chinese Agriculture," American Journal of Agricultural Economic, 73: 266-275.

Fan, Shenggen, Linxiu Zhang, and Xiaobo Zhang, (2004). "Reform, Investment, and Poverty in Rural China," Economic Development and Cultural Change, 52 (2): 395-422.

FOCAC (2012). The Fifth Ministerial Conference of the Forum on China-Africa Cooperation Beijing Action Plan (2013-2015), Retrieved from http://www.

focac.org/chnzxxx/t12846658.htm, accessed on 4 July 4, 2017.

Forum on China-Africa Cooperation, (FOCAC) (2015). "Spotlight: China's aiding Africa Paradigm of South-South Cooperation. Retrieved from http://www.

focac.org/eng/zfgx/dfzc/t1297045.htm.

Goldmann, K. (1982). Change and Stability in Foreign Policy: Détente as a Problem of

Stabilization, World Politics, 34-2, pp.230-66.

Gustavsson, J. (1998). The Politics of Foreign Policy Change: Explaining the Swedish Reorientation on EC Membership, Lund University Press, Lund, Doctoral Dissertation.

Gountin V. Maurice (2006) "China's Assistance to Africa, a Stone Bridge of Sino-African Relations". Unpublished Paper Retrieved from http://www.cctr.ust.hk/

materials/conference/china-africa/papers/Gountin, Maurice.pdf.

Jefferson, Garry H., (2008). "How has China's Economic Emergence Contributed to the Field of Economic?" Comparative Economic Studies, 50 (2): 167-209.

Jian, S. (1996). Foreign Policy Restructuring as Adaptive Behavior, China's Independent Foreign Policy 1982-1989, University Press of America, Inc. Lanham.

Hallenberg, J. (1984). Foreign Policy Change: United States Foreign Policy Toward the Soviet Union and The People's Republic of China 1961-1980, University of Stockholm, Stockholm, Doctoral Dissertation.

Herman, C. F. (1990). “Changing Course: When Governments Choose to Redirect Foreign Policy, International Studies Quarterly, Vol. 34, pp.3-21.

Holsti, K. J. (1982) Why Nations Realign: Foreign Policy Restructuring in the Postwar World, Allen \& Unwin, London, 1982.

Huxsoll, D. B (2003). Regime Change. Institutions and Foreign Policy Change, Doctoral Dissertation Submitted to the Graduate Faculty of the Louisiana State University.

Kleistra, Y. \& Mayer, I. (2001) Stability and Flux in Foreign Affairs: Modelling Policy and Organizational Change, Cooperation and Conflict, 36-4, pp. 381-414.

King, K. (2013). China's Aid and Soft Power in Africa: The Case of Education and Training. Rochester, NY: James Currey.

Krueger, Anne O. (1984). "Comparative Advantage and Development Policy Twenty Years Later. in: Moshe Syrquin, Lance Taylor and Larry E. Westphal (eds.) Economic Structure and Performance. New York: Academic Press.

Lin, Justin Yifu, (1990). “Collectivization and China's Agricultural Crisis in 1959-1961," Journal of Political Economy, 98 (6): 1228-1252. 
Lin, Justin Yifu, (1992). "Rural Reforms and Agricultural Growth in China," American Economic Review, 82 (1): 34-51.

Lin, Justin Yifu, (2007). "Development and Transition: Idea, Strategy and Viability." The Marshall Lectures for 2007-2008, October 31 and November 1, Cambridge University.

Liu Jian, Xiaoyun Li and Fuhe Liu. (2009). A Study on Poverty Reduction in Rural China, China Finance and Economics Press, Beijing.

Looy Judith (2006), Africa and China: A Strategic Partnership? African Studies Centre working paper 67/2006, African Studies Centre, The Netherlands.

Luo, Xiaopeng, (2008). "Collective Learning and Choice of Reform Path," in Learning from China: How Does China Learn? Edited by Xiaobo Zhang, Arjan de Haan and Shenggen Fan, World Scientific Series on Economic Development and Growth.

Mashingaidze, A. M. (2016) “China's Changing Foreign Policy Towards Africa: A Critical Assessment of the Possible Implications, the Case of Zimbabwe". Unpublished PhD Thesis. Retrieved from http://wiredspace.wits.ac.za/jspui/

bitstream/10539/21963/2/Dissertation\%20Final.pdf.

Mohan, G., \& Power, M. (2008). "New African Choices? The Politics of Chinese Engagement, Review of African Political Economy, Vol. 35, No. 115, pp. 23-42.

Ministry of Education, China (MOE). (2012). Retrospect and prospect on China-Africa Educational Exchanges and Cooperation in the New Century. In H. Zhang (Ed). Annual Report on Development in Africa (p. 69-76). Beijing Social Sciences Academic Press.

Ministry of Commerce (MOFCOM) (2015). “The 2014 Business Review XI: China-Africa Trade and Economic Cooperation Starts a New Chapter. Retrieved from http://english.mofcom.gov.cn/article/ztbusinessreview/new/news/201503/20150300908034.shtml Ministry of Foreign Affairs of the People Republic of China (MOFA). (2017). Remarks by Amb. Liu Xianfa at seminar on "investing in soft power capacity: China-Africa

think tank cooperation". Retrieved from: http:// www.fmprc.gov.cn/mfa_eng/wjb_ 663304/zwjg_665342/zwbd_665378/t1445723.shtml.

Oldfield, D.D. (1998). The Restructuring of Thailand's Foreign Policy Towards Laos, 1988-1991, Northern Illinois University, Doctoral Dissertation.

Onderco Michal (2007), Changing Nature of Sino-African Relations After the Second World War, http://blog.sme.sk/blog/2953/97594/onderco-china_and_africa.pdf

Ravallion, Martin, and Shaohua Chen. (2007). "China's (Uneven) Progress Against Poverty," Journal of Development Economics, 82 (1): 1-42.

Rodrik, Dani. (2008). “The New Development Economics: We Shall Experiment, But How Shall We Learn?" Brookings Development Conference, May 29-30, 2008. Boston, MA.

Shinn, D. H., \& Eisenman, J. (2012). China and Africa: A Century of Engagement, University of Pennsylvania Press, Philadelphia.

Shoko Yamada (2016), Post-Education-for-All and Sustainable Development Paradigm: Structural Changes with Diversifying Actors and Norms (International Perspectives on Education and Society, Volume 29) Emerald Group Publishing Limited, pp.iii. ISBN: 978-178441-271-5 eISBN: 978-1-78441-270-8. 
Sun, Y. (2014). China's Aid to Africa: Monster or Messiah? Brookings East Asia Commentary, Vol. 88 No.75.

Tambo, E., Ugwu, C.E, Guan, Y., Wei, D., Xiao-Ning, Xiao-Nong, Z., (2016). China-Africa Health Development Initiatives: Benefits and Implications for Shaping Innovative and EvidenceInformed National Health Policies and Programs in Sub-Saharan African Countries. International Journal of MCH and Aids. Vol. 5 Issue 2, pp.119-133.

Wen Yi. (2016) China's Rapid Rise: From Backward Agrarian Society to Industrial

Powerhouse in Just 35 Years. Federal Reserve Bank of St. Louis. Retrieved from

https://www.stlouisfed.org/publications/regional-economist/april-2016/chinas-

rapid-rise-from-backward-agrarian-society-to-industrial-powerhouse-in-just-35-years

World Bank (2016). China 2016 Poverty Reduction International Forum \& Launching Ceremony of Global Poverty Reduction and Inclusive Growth Portal Beijing, China. The World Bank, Washington DC. Retrieved From: http://www.

worldbank.org/en/news/speech/2016/05/10/bert-hofman-speech-at-the-2016-chinapovertyreduction-international-forum.

Wu, C., 2008. -China 's Foreign Policy towards Africa. The School of Government and International Affairs. Durham University. www.pol.ed.ac.uk. [Accessed on July 30, 2017]

Xu Lixin Collin, (2003) "Control, Incentives, and Competition: The Impact of Reform on Chinese State-Owned Enterprises," Economic of Transition, 8(1): 151-173.

Xinhua News Agency. (2016). "Shisanwu, Zhongguo Haixu Tuopin 5575 was ren" Retrieved from: http://newsxinhuanet.com/politics/2016-03/06/c_1118246888 5.htm.

Zhang, Xiaobo. (2006a). “Asymmetric Property Rights in China's Economic Growth". William Mitchell Law Review, 33(2):567-589.

Zhang, Xiaobo (2007). "Asymmetric Property Rights in China's Economic Growth". William Mitchell Law Review, 33 (2):567-589.

Zhu, Kangdui. (2008). “The Independent Choice of Local Government in Civil and MarketOriented Reformation Process: Research of Wenzhou Model of Interaction Between Civilian and Government." in Learning from China: How Does China Learn? Edited by Xiaobo Zhang, Arjan de Haan and Shenggen Fan, World Scientific Series on Economic Development and Growth. 